\title{
SELECTION AND OPTIMIZATION OF MATERIAL FOR 3D PRINTING USING GREY RELATIONAL ANALYSIS
}

\author{
Vishal Vijay Gholkar \\ Design Engineer \\ Ghatge Patil Industries Ltd. Kolhapur
}

\begin{abstract}
D printing is new emerging technology that growing fast and lots of research carried out on this topic. This paper show that there are different materials available for 3D printing, but we don't know which one is the better for printing if there is no requirement of special material. Every material shows different properties so it is difficult to select a single material for printing. For that purpose I used Grey Relational Analysis is a one of the optimization technique to select best material for printing.
\end{abstract}

Keywords - 3D Printing, AM, GRA

\section{INTRODUCTION}

\subsection{Additive manufacturing}

The term AM including many technologies subsets like Rapid Prototyping (RP), 3D Printing, Direct Digital Manufacturing, Layered manufacturing and additive fabrication [1].

AM builds products by adding one layer over another rather than by subtracting material from a larger piece of material like cutting out a helical gear from a AISI 4140 bar that is, "subtractive" manufacturing. This state small distinction adding rather than subtracting means everything. Assembly lines and supply chains can be reduced or eliminated for many products [2].

\subsection{Classification of Additive Manufacturing}

Liquid based technology:

$>$ Stereo lithography (SLA)

$>$ High viscosity Jetting

$>$ Direct light processing technique

$>$ The maple process

Powder based techniques:

$>$ Selective Laser Sintering (SLS)

$>$ Direct Metal Laser Sintering (DMLS)

$>$ Selective laser melting

$>$ Selective inhibition sintering

$>$ Electro photography layered manufacturing

$>$ Selective masking sintering

$>$ Fused metal deposition

$>$ Electron beam melting
Solid based techniques:

$>$ Sheet stalking technique

$>$ Fused deposition modeling (FDM) [3].

\subsection{D Printing}

The 3D printing is process which builds a three-dimensional object from a Computer Aided Design (CAD) model, by successively adding material layer by layer that's why it is called as additive manufacturing [4].

3D printing is also emerging as an energy efficient technology that can provide environmental efficiencies in terms of both the manufacturing process itself, utilizing up to $90-95 \%$ of standard materials, and throughout the products operating life, through lighter and stronger design. It is used in variety of industries including jewelry, footwear, industrial design, engineering and construction, architecture, automotive, aerospace, dental and medical industries, education and consumer products [5].

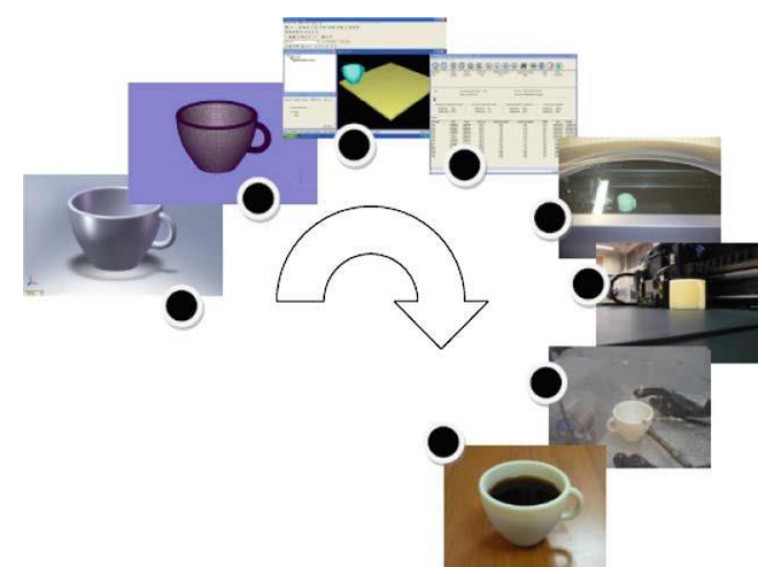

Fig 1:- 3D printing process [5].

Stepwise procedure of $3 \mathrm{D}$ printing

We will refer to eight key steps in the process sequence:

1. Conceptualization and CAD

2. Conversion to STL

3. Transfer and manipulation of STL file on AM machine

4. Machine setup 
5. Build

6. Part removal and cleanup

7. Post-processing of part

8. Application

\subsection{Fused Deposition Modeling (FDM)}

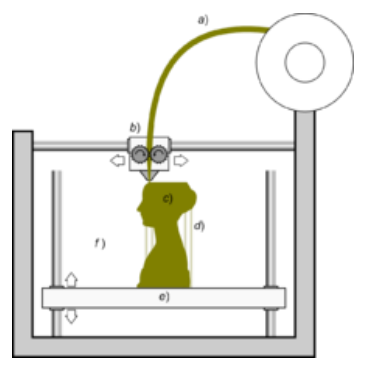

$$
\begin{aligned}
& \text { a }- \text { Filament } \\
& \text { b }- \text { Nozzle } \\
& \mathrm{c}-\text { Object } \\
& \mathrm{d}-\text { Support } \\
& \mathrm{e}-\text { Bed }
\end{aligned}
$$

Fig 2:- Fused Deposition Modeling (FDM)

Fused Deposition Modeling is one of the most widely used additive manufacturing processes for printing and fabricating plastic parts. FDM works on an "additive" principle by laying down material in layers; a plastic filament or metal wire is unwound from a coil and supplies material to produce a part. The process works by melting plastic filament that is deposited, through a heated extruder. Thickness of deposited layer onto a build platform according to the 3D data supplied to the printer [6].

\subsection{D Printing Materials}

After different research carried out on 3D Printing materials following are some standard materials that use for $3 \mathrm{D}$ printing to print a better quality objects. We use GRA optimization technique for selection of a best material for 3D printing to improve the quality of print [7].

1. ABS

- ABS is chemically resistant to water.

- Low Cost

- Good impact and wear resistance

- Less oozing and stringing

- Good heat resistance [8].

\section{PLA}

- PLA is a biodegradable and low toxicity polyester PLA is considered an ecofriendly thermoplastic

- Low Cost

- Stiff and good strength

- Good dimensional accuracy
- Good shelf life [8].

\section{NYLON}

- Tough and partially flexible

- High impact resistance

- No unpleasant odor while printing

- Good abrasion resistance [7].

4. ASA

- ASA is a material that has similar properties to ABS, but has a greater resistance to UV rays.

- High impact and wear resistance

- High glass transition temperature [9].

\section{PETG}

- Water resistance

- Good impact resistance

- Glossy and smooth surface finish

- Adheres well to the bed with negligible warping

- Mostly odorless while printing

- $\quad$ Prone to wear [7].

\section{CARBON FIBER}

- Increased strength and stiffness

- Very good dimensional stability

- Light weight [10].

\section{POLYCARBONATE}

- High strength and durability

- Impact resistant

- High heat resistance

- Naturally transparent

- Bendable without breaking [7].

\section{POLYPROPYLENE}

- Good impact and fatigue resistance

- Semi-flexible

- Good heat resistance

- Lightweight

- Smooth surface finish [7].

\section{WOOD FILAMENT}

- Wood filaments combine a PLA base material with cork, wood dust, or other derivatives, giving the models a real wooden look and feel

- Wood-textured finish is aesthetically appealing

- Does not need any expensive wear resistant nozzles

- Aromatic and pleasant smelling [7].

10. PVA

- PVA, is a water-soluble polymer

- PVA is a colorless \& odorless

- It's also low-toxicity [10]. 
Table -1 Material Properties

\begin{tabular}{|c|c|c|c|c|c|c|c|c|c|c|}
\hline Properties & ABS & PLA & NYLON & ASA & PETG & $\mathbf{C F}$ & $\mathbf{P C}$ & $\mathbf{P P}$ & WOOD & PVA \\
\hline Cost & Low & Low & High & High & High & High & High & High & High & High \\
\hline $\begin{array}{l}\text { Impact\& } \\
\text { Wear } \\
\text { Resistance }\end{array}$ & High & - & High & High & - & - & High & High & - & - \\
\hline $\begin{array}{c}\text { Heat } \\
\text { Resistance }\end{array}$ & High & Low & High & High & - & - & High & High & - & - \\
\hline $\begin{array}{c}\text { Abrasive } \\
\text { Resistance }\end{array}$ & - & - & High & - & - & - & - & - & - & \\
\hline $\begin{array}{l}\text { Chemical } \\
\text { Resistance }\end{array}$ & - & - & - & - & High & - & - & - & - & - \\
\hline Uv Resistance & - & - & - & High & - & - & - & - & - & - \\
\hline $\begin{array}{c}\text { Fatigue } \\
\text { Resistance }\end{array}$ & - & - & High & - & High & - & High & High & - & High \\
\hline $\begin{array}{c}\text { Water } \\
\text { Resistance }\end{array}$ & - & - & - & - & High & - & - & High & - & - \\
\hline Oozing & Less & More & - & - & - & More & More & - & - & - \\
\hline Wrapping & Heavy & - & Heavy & - & No & - & - & Heavy & - & - \\
\hline $\begin{array}{l}\text { Surface } \\
\text { Finish }\end{array}$ & Smooth & - & - & - & Smooth & - & - & Smooth & - & - \\
\hline $\begin{array}{c}\text { Dimensional } \\
\text { Accuracy }\end{array}$ & Low & High & - & - & - & High & - & - & - & - \\
\hline Ordure & Pungent & - & No & - & No & - & - & - & Pleasant & - \\
\hline Strength & - & High & - & - & - & High & - & Low & - & - \\
\hline Brittle & - & Yes & - & - & - & - & - & - & - & - \\
\hline Tough & - & - & Yes & - & - & - & - & - & - & - \\
\hline Flexible & - & - & Yes & - & - & - & - & - & - & - \\
\hline Heated Bed & Required & Not & - & - & - & Not & - & - & Not & - \\
\hline $\begin{array}{l}\text { Moist and } \\
\text { Humidity } \\
\text { Environment }\end{array}$ & - & - & $\begin{array}{c}\text { Not } \\
\text { Suitable }\end{array}$ & - & - & - & $\begin{array}{c}\text { Not } \\
\text { Suitable }\end{array}$ & - & - & - \\
\hline Lightweight & - & - & - & - & - & Yes & - & - & - & - \\
\hline $\begin{array}{c}\text { Extrusion } \\
\text { Temp }\end{array}$ & $\begin{array}{c}220- \\
250^{\circ} \mathrm{C} \\
\end{array}$ & $\begin{array}{c}190- \\
200^{\circ} \mathrm{C} \\
\end{array}$ & $\begin{array}{c}220- \\
270^{\circ} \mathrm{C} \\
\end{array}$ & $\begin{array}{c}235- \\
255^{\circ} \mathrm{C} \\
\end{array}$ & $\begin{array}{c}230- \\
250^{\circ} \mathrm{C} \\
\end{array}$ & $\begin{array}{c}200- \\
230^{\circ} \mathrm{C} \\
\end{array}$ & $\begin{array}{c}260- \\
310^{\circ} \mathrm{C} \\
\end{array}$ & $\begin{array}{c}220- \\
250^{\circ} \mathrm{C} \\
\end{array}$ & $\begin{array}{c}190- \\
220^{\circ} \mathrm{C} \\
\end{array}$ & $\begin{array}{c}185- \\
200^{\circ} \mathrm{C} \\
\end{array}$ \\
\hline Flexible & - & - & Yes & - & - & - & - & Yes & - & Yes \\
\hline $\begin{array}{c}\text { Bed } \\
\text { Temperature }\end{array}$ & $95-100^{\circ} \mathrm{C}$ & $\begin{array}{c}45- \\
60^{\circ} \mathrm{C}\end{array}$ & $70-90^{\circ} \mathrm{C}$ & $\begin{array}{c}90- \\
110^{\circ} \mathrm{C}\end{array}$ & $\begin{array}{l}75- \\
90^{\circ} \mathrm{C}\end{array}$ & $\begin{array}{l}45- \\
60^{\circ} \mathrm{C}\end{array}$ & $\begin{array}{c}80- \\
120^{\circ} \mathrm{C}\end{array}$ & $\begin{array}{c}85- \\
100^{\circ} \mathrm{C}\end{array}$ & $45-60^{\circ} \mathrm{C}$ & $\begin{array}{c}45- \\
60^{\circ} \mathrm{C}\end{array}$ \\
\hline
\end{tabular}

\subsection{Material Properties}

Following are some properties of material shows in table no 1 that collected from a well known source [7]. Properties like Stiffness, Durability, and Printability of materials are given in a rank between $0-10$. All the values of ultimate strength are taken as average between two values.

1. Ultimate Strength: - The maximum stress that material can withstand before breaking.
2. Stiffness: - Measure how difficult it is a bend to given material.

3. Durability: - Combination of Heat, Fatigue, Water, UV and Chemical resistance.

4. Printability: - How easy it is print with this materials best such factors warping, clogging etc. 


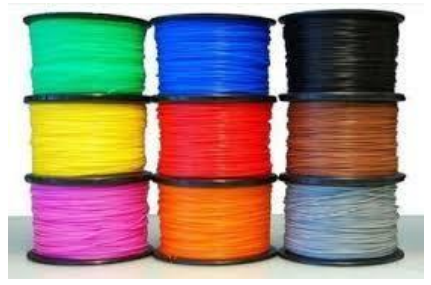

Fig 3:- 3D Printing Filament

\subsection{Grey Relational Analysis}

Tosun Nihat \& Pihtili Hasim (2009) in their work addressed info about GRA according to their research in a complex multivariate system, the relationship among various factors is usually unclear. Such systems are often called as "gray" implying poor, incomplete, and uncertain information. Gray relational analysis is an impacting measurement method in gray system theory that analyzes uncertain relations between one main factor and all the other factors in a given system. When experiments are ambiguous or when the experimental method cannot be carried out exactly, gray analysis helps to compensate for the shortcomings in statistical regression [11].

For data preprocessing in the gray relational analysis process, "the lower is better" used for Price and "the larger is better" used for Ultimate strength, Stiffness, Durability, Printability are the indication of better performance in 3D Printing process.

\section{METHODOLOGY}

Selection and optimization of various materials for FDM. Using Grey Relational Analysis

Raykar Sunil in their work addressed procedure for GRA. [12].

\section{Step 1: Normalization of Data}

The first step in grey relational analysis is normalization of data which is performed to prepare raw data for the analysis. Normalization of data in the range between zero and unity is also called as the grey relational generation. In this investigation "smaller-the-better" (1) criterion is used for normalization of Price and "Larger-the-better"(2) criterion is used for normalization of Ultimate Strength, Stiffness, Durability, Printability.

$$
\begin{gathered}
x_{i}^{*}(k)=\frac{\operatorname{maxx}_{i}^{(o)}(k)-x_{i}^{(o)}(k)}{\operatorname{maxx}_{i}^{(o)}(k)-\min _{i}^{(o)}(k)} \\
x_{i}^{*}(k)=\frac{x_{i}^{(o)}(k)-\min ^{(o)}(k}{\operatorname{maxx}_{i}^{(o)}(k)-\min _{i}^{(o)}(k)}
\end{gathered}
$$

Step 2: Determination of deviation sequence

The deviation sequence $\Delta 0_{i}(k)$ is the absolute difference between the reference sequence $x^{*}(k)$ and the comparability sequence

$*()$

3 as:

$$
\Delta 0_{i}(k)=\underset{0}{\left|x^{*}(k)-x^{*}(k)\right|}
$$

Step 3: Determination of Grey Relational Coefficient GRC for all the sequences expresses the relationship between the ideal (best) and actual normalized $\mathrm{S} / \mathrm{N}$ ratio. If the two sequences agree at all points, then their grey relational coefficient is 1 . The grey relational coefficient $\gamma\left(x_{0}(k), x_{i}(k)\right)$ can be expressed by Eq. 4 .

$$
\underset{0}{\gamma(x), x(k))}=\frac{\Delta \min +\zeta \Delta \max }{\Delta_{0 i}(k)+\zeta \Delta_{\max }}
$$

Where, $\Delta \min$ is the smallest value of $\Delta 0_{i}(k)=$ $\min _{i} \min _{k}\left|x_{0}^{*}(k)-x_{i}^{*}(k)\right|$ and $\Delta \max$ is the largest value of $\Delta 0_{i}(k)=\max _{i} \max _{k}\left|x_{0}^{*}(k)-{ }_{i} x^{*}(k)\right|_{0} x^{*}(k)$ is the ideal normalized $\mathrm{S} / \mathrm{N}$ ratio, $x_{i}^{*}(k)$ is the normalized comparability sequence, and $\zeta$ is the distinguishing coefficient. The value of $\zeta$ can be adjusted with the systematic actual need and defined in the range between 0 and 1 ; here it istaken as 0.5 .

\section{Step 4: Determination of Grey Relational Grade}

$$
\begin{aligned}
& \gamma(x x)={ }^{1} \Sigma^{m} \gamma(x(k), x(k)) \\
& \begin{array}{llll}
o, i & \bar{m} & \mathrm{i}=1 & 0
\end{array}
\end{aligned}
$$

The overall evaluation of the multiple performance characteristics is based on the grey relational grade. The grey relational grade is an average sum of the grey relational coefficients

\section{Step 5: Determination of Optimal parameters}

The grey relational grade calculated for each sequence is taken as a response for the further analysis. The larger-the-better quality characteristic was used for analyzing the GRG, since a larger value indicates the better performance of the process. The response table of Taguchi method was employed here to calculate the average grey relational grade for each factor level. In this, the grouping of the grey relational grades was done initially by the factor level for each column in the orthogonal array and then by averaging them

\section{DESIGN OF EXPERIMENT}

Table -2 Material Properties

\begin{tabular}{|c|c|c|c|c|c|}
\hline MATERIAL & U/S & S & D & P & PR \\
\hline ABS & 40 & 5 & 8 & 1750 & 8 \\
\hline PLA & 65 & 7.5 & 4 & 1750 & 9 \\
\hline NYLON & 65 & 5 & 10 & 3150 & 8 \\
\hline ASA & 55 & 5 & 10 & 2800 & 7 \\
\hline PETG & 53 & 5 & 8 & 2800 & 9 \\
\hline $\begin{array}{c}\text { CARBON } \\
\text { FIBER }\end{array}$ & 45 & 10 & 3 & 3850 & 8 \\
\hline $\begin{array}{c}\text { POLYCARB } \\
\text { ONATE }\end{array}$ & 72 & 6 & 10 & 3850 & 6 \\
\hline $\begin{array}{c}\text { POLYPROP } \\
\text { YLENE }\end{array}$ & 32 & 4 & 9 & 6300 & 4 \\
\hline WOOD & 46 & 8 & 3 & 2800 & 8 \\
\hline PVA & 78 & 3 & 7 & 5250 & 5 \\
\hline
\end{tabular}


Published Online November 2020 in IJEAST (http://www.ijeast.com)

\section{Step 1: Normalization of Data}

Table - 3 Normalization of data

\begin{tabular}{|c|c|c|c|c|}
\hline \multicolumn{5}{|c|}{ Normalization of data } \\
\hline U/S & S & D & P & PR \\
\hline 0.2830 & 0.2857 & 0.7143 & 1 & 0.8000 \\
\hline 0.7547 & 0.6429 & 0.1429 & 1 & 1.0000 \\
\hline 0.7547 & 0.2857 & 1.0000 & 0.6923 & 0.8000 \\
\hline 0.5660 & 0.2857 & 1.0000 & 0.7692 & 0.6000 \\
\hline 0.5283 & 0.2857 & 0.7143 & 0.7692 & 1.0000 \\
\hline 0.3774 & 1.0000 & 0.0000 & 0.5384 & 0.8000 \\
\hline 0.8868 & 0.4286 & 1.0000 & 0.5384 & 0.4000 \\
\hline 0.1321 & 0.1429 & 0.8571 & 0 & 0.0000 \\
\hline 0.3962 & 0.7143 & 0.0000 & 0.7692 & 0.8000 \\
\hline 1.0000 & 0.000 & 0.5714 & 0.2307 & 0.2000 \\
\hline
\end{tabular}

Table - 4 Determine Deviation Sequence

\begin{tabular}{|c|c|c|c|c|}
\hline \multicolumn{5}{|c|}{ Determine Deviation Sequence } \\
\hline U/S & S & D & P & PR \\
\hline 0.7170 & 0.7143 & 0.2857 & 0.0000 & 0.2000 \\
\hline 0.2453 & 0.3571 & 0.8571 & 0.0000 & 0.0000 \\
\hline 0.2453 & 0.7143 & 0.0000 & 0.3077 & 0.2000 \\
\hline 0.4340 & 0.7143 & 0.0000 & 0.2308 & 0.4000 \\
\hline 0.4717 & 0.7143 & 0.2857 & 0.2308 & 0.0000 \\
\hline 0.6226 & 0.0000 & 1.0000 & 0.4615 & 0.2000 \\
\hline 0.1132 & 0.5714 & 0.0000 & 0.4615 & 0.6000 \\
\hline 0.8679 & 0.8571 & 0.1429 & 1.0000 & 1.0000 \\
\hline 0.6038 & 0.2857 & 1.0000 & 0.2308 & 0.2000 \\
\hline 0.0000 & 1.0000 & 0.4286 & 0.7692 & 0.8000 \\
\hline
\end{tabular}

Step 3: Determination of Grey Relational Coefficient

Table -5 Determination of Grey relational Coefficient

\begin{tabular}{|c|c|c|c|c|}
\hline \multicolumn{5}{|c|}{ Determination of Grey relational Co-efficient } \\
\hline U/S & S & D & P & PR \\
\hline 0.4109 & 0.4118 & 0.6364 & 1.0000 & 0.7143 \\
\hline 0.6709 & 0.5833 & 0.3684 & 1.0000 & 1.0000 \\
\hline 0.6709 & 0.4118 & 1.0000 & 0.6190 & 0.7143 \\
\hline 0.5354 & 0.4118 & 1.0000 & 0.6840 & 0.5556 \\
\hline 0.5146 & 0.4118 & 0.6364 & 0.6840 & 1.0000 \\
\hline 0.4454 & 1.0000 & 0.3333 & 0.5200 & 0.7143 \\
\hline 0.8154 & 0.4667 & 1.0000 & 0.5200 & 0.4545 \\
\hline 0.3655 & 0.3684 & 0.7778 & 0.3330 & 0.3333 \\
\hline 0.4530 & 0.6364 & 0.3333 & 0.7143 & 0.7143 \\
\hline 1.0000 & 0.3333 & 0.5385 & 0.3846 & 0.3846 \\
\hline
\end{tabular}

Step 4: Determination of Grey Relational Grade Table -6 Determination of Gray Relational Grade

\begin{tabular}{|c|c|}
\hline Grade & Rank \\
\hline 0.6347 & 6 \\
\hline 0.7245 & 1 \\
\hline 0.6832 & 2 \\
\hline 0.6374 & 5 \\
\hline 0.6494 & 4 \\
\hline 0.6026 & 7 \\
\hline 0.6513 & 3 \\
\hline 0.4357 & 10 \\
\hline 0.5642 & 8 \\
\hline 0.5301 & 9 \\
\hline
\end{tabular}

Result and analysis Table - 7 Rank

\begin{tabular}{|c|c|c|c|c|c|c|}
\hline MATERIAL & U/S & S & D & P & PR & R \\
\hline ABS & 40 & 5 & 8 & 1750 & 8 & 6 \\
\hline PLA & $\mathbf{6 5}$ & $\mathbf{7 . 5}$ & $\mathbf{4}$ & $\mathbf{1 7 5 0}$ & $\mathbf{9}$ & $\mathbf{1}$ \\
\hline NYLON & 65 & 5 & 10 & 3150 & 8 & 2 \\
\hline ASA & 55 & 5 & 10 & 2800 & 7 & 5 \\
\hline PETG & 53 & 5 & 8 & 2800 & 9 & 4 \\
\hline $\begin{array}{c}\text { CARBON } \\
\text { FIBER }\end{array}$ & 45 & 10 & 3 & 3850 & 8 & 7 \\
\hline $\begin{array}{c}\text { POLYCARB } \\
\text { ONATE }\end{array}$ & 72 & 6 & 10 & 3850 & 6 & 3 \\
\hline $\begin{array}{c}\text { POLYPROP } \\
\text { YLENE }\end{array}$ & 32 & 4 & 9 & 6300 & 4 & 10 \\
\hline WOOD & 46 & 8 & 3 & 2800 & 8 & 8 \\
\hline PVA & 78 & 3 & 7 & 5250 & 5 & 9 \\
\hline
\end{tabular}
U/S - Ultimate Strength
S - Stiffness
D - Durability
$\mathrm{P}-$ Price
PR - Printability

\section{$\mathrm{R}-$ Rank}

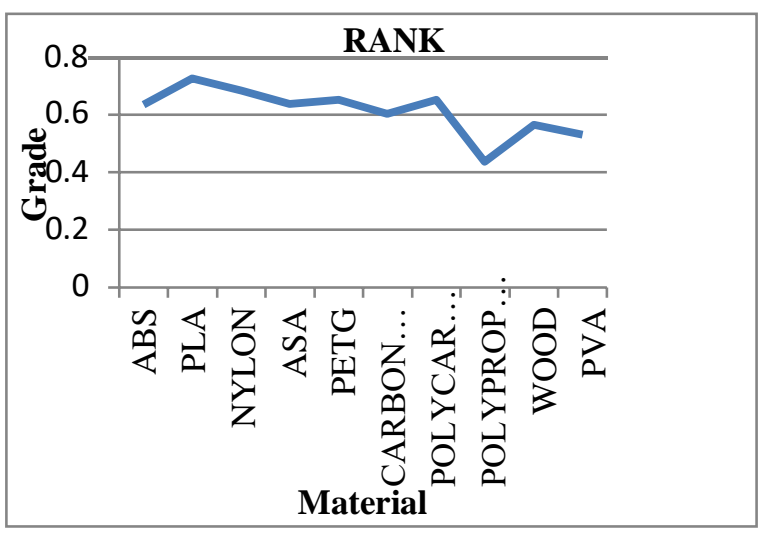

Fig 4:- Result 


\section{International Journal of Engineering Applied Sciences and Technology, 2020 \\ Vol. 5, Issue 7, ISSN No. 2455-2143, Pages 308-313 \\ Published Online November 2020 in IJEAST (http://www.ijeast.com)}

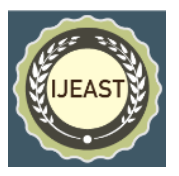

[3] Hopkinson N, \& Hague R.J.M \& Dickens P.M (2006) Rapid Manufacturing: An Industrial Revaluation For The Digital Age Edition N. pp.(5579)

\section{RESULT AND DISCUSSION}

In 3D Printing process minimum Price and maximum Ultimate strength, Stiffness, Durability and Printability are an indication of better performance. For data preprocessing in the gray relational analysis process, Price was taken as the "lower is better", and Ultimate strength, Stiffness, Durability and Printability ware taken as the "larger is better",

In the first step we normalize data using Eq. 1 and Eq. 2 All the sequences after data preprocessing using Eq. 1 and Eq. 2 are listed in Table 3 and denoted as $x^{*}(k)$ and $x^{*}(k)$ for comparability sequences and reference sequence.

In second step we calculate Deviation sequence using Eq. 3 are listed in Table 4.

In $3^{\text {rd }}$ step we calculate grey relational coefficient using Eq. 4 are listed in Table 5.

In $4^{\text {th }}$ step we calculate grey relational grade using Eq.5 are listed in Table 6 . The grey relational grade is an average sum of the grey relational coefficients.

According to the performed experimental design, it is clearly observed from Table 7 and Fig. 4 that PLA material has the highest gray relational grade. Therefore, PLA material has minimum Price and maximum Ultimate strength, Stiffness, Durability and Printability (i.e., the best multi performance characteristics) among the all materials.

\section{CONCLUSION}

The Grey Relational Analysis technique shows that PLA is best suitable material for 3D printing according to their different properties and price. If there is no requirement of any special properties.

\section{RANK}
1. PLA
2. NYLON
3. POLYCARBONATE
4. PETG
5. ASA
6. ABS
7. CARBON FIBER
8. WOOD FILAMENT
9. PVA
10. POLYPROPYLENE

\section{REFERENCES}

[1] Additive manufacturing https://www.additivemanufacturing.com accessed on 25/3/2020 at 6.19 PM IST.

[2] Campbell Thomas, Williams Christopher, Ivanovo Olga, Garrett Banning (October 2011). Could 3D Printing Change the World? Technologies, Potential, and Implications of Additive Manufacturing", Strategic Foresight report. (pp. 1-15)
[4] Wikipedia

https://www.wikipedia.org/wiki/3D_printing accessed on 25/3/2020 at 6.29 PM IST.

[5] Gibson Ian, Rosen David, Stucker Brent, (2015) “Additive ManufacturingTechnologies3D Printing, Rapid Prototyping, and Direct Digital Manufacturing", Second Edition. pp.(1-17)

[6] Liou Frank (2008) Rapid Prototyping and Engineering Applications: A Toolbox for Prototype Development. pp. (257-260)

[7] Simplify3D https://www.simplify3d.com/support/materialsguide accessed on 25/3/2020 at 11:56 PM IST.

[8] Carbon Nanotubes and Graphene as Additives in 3D Printing http://dx.doi.org/10.5772/63419 accessed on 25/3/2020 at 03:56 PM IST

[9] 3D Natives https://www.3dnatives.com/en/plasticsused-3d-printing accessed on 12/09/2020 at 03:20 PM IST.

[10] All 3DP https://all3dp.com/2/pva-filamentexplained- and-compared/ accessed on 12/09/2020 at 03:50 PM IST.

[11]Tosun Nihat \& Pihtili Hasim.(2009) Gray relational analysis of performance characteristics in MQL milling of $7075 \mathrm{Al}$ alloy. pp.(509-515)

[12]Raykar Sunil J \& Dabade Uday (2017) A Optimization of High Pressure Coolant Assisted Turning of Inconel 718 withMulti-performance Characteristics pp.(659-664) 